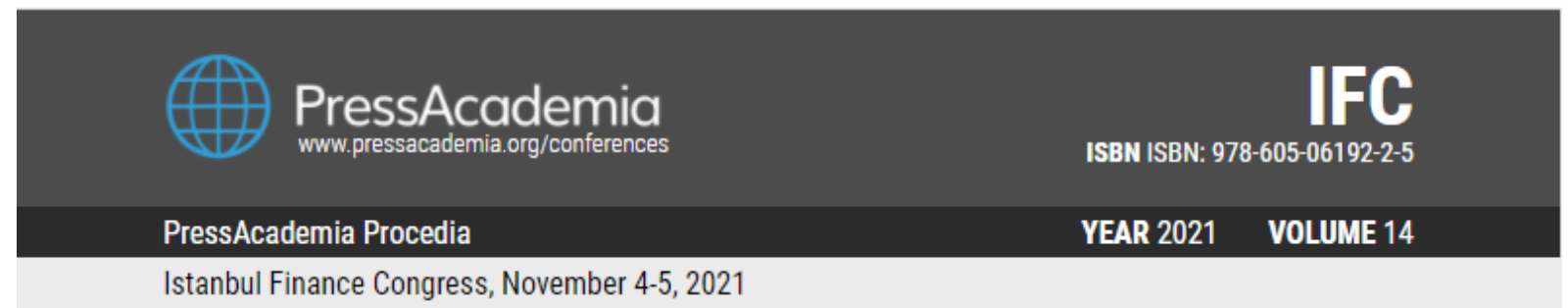

\title{
TECHNICAL ANALYSIS OF OIL PRICES USING NICKEL FIBONACCI RATIOS
}

\author{
DOI: 10.17261/Pressacademia.2021.1505 \\ PAP- V.14-2021(31)-p.126-127
}

Umit Tura ${ }^{1}$, Mucahit Akbiyik ${ }^{2}$, Seda Yamac Akbiyik ${ }^{3}$, Ferudun Kaya ${ }^{4}$, Elif Erer ${ }^{5}$, Mehtap Calis ${ }^{6}$

${ }^{1}$ Bolu Abant İzzet Baysal University, Department of Management and Organisation, Bolu, Turkey. umittura@ibu.edu.tr, ORCID: 0000-0001-6329-5334

${ }^{2}$ Beykent University, Department of Mathematics, Istanbul, Turkey. mucahitakbiyik@beykent.edu.tr, ORCID: 0000-0002-0256-1476

${ }^{3}$ Istanbul Gelisim University, Department of Computer Engineering, Istanbul, Turkey. syamac@gelisim.edu.tr, ORCID: 0000-0003-1797-674X

${ }^{4}$ Bolu Abant İzzet Baysal University, Department of Finance and Banking, Bolu, Turkey. ferudunk@ibu.edu.tr, ORCID: 0000-0002-8930-9711

Independent Researcher, İzmir, Turkey.

eliferer@hotmail.com, ORCID: 0000-0002-2238-4602

${ }^{6}$ Independent Researcher, Bolu, Turkey.

mehtapdogan0709@gmail.com, ORCID: 0000-0003-4190-3583

\section{To cite this document}

Tura,U., Akbiyik, M., Yamac Akbiyik, S., Kaya, F., Erer, E., Calis, M., (2021). Technical analysis of oil prices using nickel Fibonacci ratios. PressAcademia Procedia (PAP), 14, 126-127.

Permanent link to this document: $h$ ttp://doi.org/10.17261/Pressacademia.2021.1505

Copyright: Published by PressAcademia and limited licensed re-use rights only.

\section{ABSTRACT}

Purpose- The purpose of this study is to investigate support and resistance levels of oil prices which have crucial impacts on economic activities in terms of Nickel Fibonacci ratios and to compare Nickel Fibonacci ratio with Fiboancci ratio based on technical analysis. Oil price is one of the main factors impacting macroeconomic indicators. It is assumed for oil prices to be endogenous since the fluactions in oil prices are affected by the global economic activity (Hamilton, 2003; Kilian, 2008; Hamilton, 2009; He et. al., 2010; Lippi and Nobili, 2012; Cashin et. al., 2014; Baumeister and Kilian, 2016). The serious flucations in oil prices have occured since 1970s, which leads to economic fluctuations. Excessive fluactions in oil prices may influence the certain industries. Investors expect a close relationship between oil prices and financial market since oil prices have a crucial role on the economy (Huang et. al., 1996; El-Sharif et. al., 2005; Cong et. al., 2008; Kilian and Park, 2009; Narayan and Sharma, 2011; Narayan and Gupta, 2015). Thus, prediction of oil prices is of importance for investors and policy makers to make hedging strageties.

Methodology- The study employs Nickel ratios based on technical analysis. In the study, weekly, daily, hourly and half-hourly data are used and drawn such as retracement, fan, arcs and time zones to exhibit efficiency of Nickel Fibonacci and Fibonacci ratios. Technical analysis is a method examining past price movements to forecast future prices based on historical prices. It is observed that financial asset prices rise, decrease and repeat their behaviors. The aim of technical analysis is for investors to make profit by determining which level price of a financial asset will buy and sell. By means of this method, buying and selling points of a financial asset is determined by applying formation, indicator and ascillator analysis considering past price movements and volume of a financial asset, and thereby which way its price will move is predicted. Many technical analysis methods state that withdraws in financial asset prices generally disappear based on certain percentages of price movements, and financial asset prices can be effectively estimated by Fibonacci sequence (Pring, 2014: 29). Technical analysts use a variety of technical analysis methods to predict price movements in the stock market. The Fibonacci ratio is a well-known method for predicting the market. In the literature, Fibonacci sequence is used in technical analysis. However, these levels may be unsufficent in predicting of prices. Unlike the liteature, in this study the ratios from Nickel Fibonacci sequence is applied in addition to the ratios from Fibonacci sequence. Nickel Fibonacci sequence has initial values of $\mathrm{N}_{0}=1$ and $\mathrm{N}_{1}=1$. This sequence is created by adding three times of previous number of Nickel Fibonacci to its previous value. As investigated the literature, it is seen for Nickel Fibonacci ratios not to be used in technical analysis. So, to the best of our knowledge, this study is the first paper to calculate Nickel Fibonacci ratios used in technical analysis.

Findings- The analysis reveals that support and resistance levels determined by using Nikel ratios have an important role on changes in oil prices and investment decisions. As compared to Fibonacci ratios, the support and resistance points from Nickel Fibonacci are determined to be more significant levels. Also, retracement, fan, arcs and time zones graph generated by Fibonacci and Nickel Fibonacci ratios using weekly, daily, four hourly and half-hourly data indicate that the levels based on Nickel Fibonacci ratios detect more important points than the levels based on Fibonacci ratios. However, it can be stated that more effective results are obtained when Fibonacci and Nickel Fibonacci ratios are used together.

Conclusion- Based upon the analysis Findings it may be concluded that Nickel Fibonacci ratios are an important indicator to be considered in technical analysis. In today's financial markets in which financial technologies develop rapidly, it is seen for robotic transactions to become 
widespread and and for technical levels to be of importance. The findings from this study reveal a new indicator to be used in technical analysis.

Keywords: Oil prices, commodity market, technical analysis, Nickel Fibonacci sequence, Nickel Fibonacci ratios

JEL Codes: 013, G10, C60

\section{REFERENCES}

Baumeister, C., \& Kilian, L. (2016). Forty years of oil price fluctuations: Why the price of oil may still surprise us. Journal of Economic Perspectives, 30(1), 139-60.

Cashin, P., Mohaddes, K., Raissi, M., \& Raissi, M. (2014). The differential effects of oil demand and supply shocks on the global economy. Energy Economics, 44, 113-134.

Cong, R. G., Wei, Y. M., Jiao, J. L., \& Fan, Y. (2008). Relationships between oil price shocks and stock market: An empirical analysis from China. Energy Policy, 36(9), 3544-3553.

El-Sharif, I., Brown, D., Burton, B., Nixon, B., \& Russell, A. (2005). Evidence on the nature and extent of the relationship between oil prices and equity values in the UK. Energy economics, 27(6), 819-830.

Hamilton, J. D. (2003). What is an oil shock?. Journal of econometrics, 113(2): 363-398.

Hamilton, J. D. (2009). Causes and Consequences of the Oil Shock of 2007-08 (No. w15002). National Bureau of Economic Research.

He, Y., Wang, S., \& Lai, K. K. (2010). Global economic activity and crude oil prices: A cointegration analysis. Energy Economics, 32(4), 868-876.

Huang, R. D., Masulis, R. W., \& Stoll, H. R. (1996). Energy shocks and financial markets. The Journal of Futures Markets (1986-1998), 16(1), 1.

Kilian, L. (2008). The economic effects of energy price shocks. Journal of economic literature, 46(4), 871-909.

Kilian, L., \& Park, C. (2009). The impact of oil price shocks on the US stock market. International Economic Review, 50(4), $1267-1287$.

Lippi, F., \& Nobili, A. (2012). Oil and the macroeconomy: a quantitative structural analysis. Journal of the European Economic Association, 10(5), 1059-1083.

Narayan, P. K., \& Gupta, R. (2015). Has oil price predicted stock returns for over a century?. Energy Economics, 48, 18-23.

Narayan, P. K., \& Sharma, S. S. (2011). New evidence on oil price and firm returns. Journal of Banking \& Finance, 35(12), 3253-3262.

Pring, M. J. (2014). Study Guide for Technical Analysis Explained Fifth Edition. McGraw Hill Professional. 